The Impact of the Basel Capital Requirements on The Performance of ...

Ahmed Yousif Abd El-Razek

\title{
The Impact of the Basel Capital Requirements on The Performance of Egyptian Banks
}

\section{Dr. Ahmed Sakr}

Department of Finance and Accounting College of Management and Technology Arab Academy for Science and Technology

\section{Ahmed Yousif Abd El-Razek}

Master researcher in Management and Technology Arab Academy for Science and Technology

\section{ABSTRACT}

The study investigated The Impact of the Basel Capital Requirements on The Performance of Egyptian Banks, using 14 years of data, which cover the period 2004-2018. This thesis empirically investigates two issues. Firstly, Research of difference in financial performance after the application of Basel II in terms of capital adequacy for the period (2004-2007) to the period (2009-2012). Secondly, Investigate the Impact of the Basel Capital Requirements on The Performance of Egyptian Banks, by research to effect of Capital Adequacy in the period (2009-2018) on Financial Performance. through A Return on Equity, Return on Assets, Net Interest Margin and Non-Performing Loan as dependent Variable, On the Other Hand Independent Variable Represents Capital Adequacy Ratio and Controlled Variable Are Bank Size

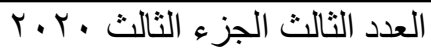

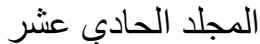


The Impact of the Basel Capital Requirements on The Performance of ...

Ahmed Yousif Abd El-Razek

and Time Period.For the first issue, the results of the study found Financial Indicators (ROA\&ROE\&NIM\&NPL) Improved After the Application of Basel II With Capital Adequacy. For the second issue, the results of the study found positive Relationship between Return on Equity, Return on Assets, Net Interest Margin and Capital Adequacy Ratio on The Other Hand The results of the study found negative Relationship between Non-Performing Loan and Capital Adequacy Ratio.

\section{1) Introduction}

The Basel Committee on Banking Supervision was recognized by the central bank governors of the Group of Ten countries in 1974 reaction the turmoil in international markets. It is based at the Bank for International Settlements in Basel (BIS) to improve global knowledge and quality of global supervision, leading to better financial stability. the commission has implemented a set of international standards for banking regulation, most notably its flagship publications on capital adequacy agreements known as Basel I, Basel II and, most recently, Basel III.

There was strong recognition within the Committee of the urgent need for a multinational agreement to strengthen the stability of the international banking system. After comments on a consultation paper published in December 1987, the G-10 rulers approved a capital measurement system commonly referred to as the Basel Capital Accord and issued to banks in 
The Impact of the Basel Capital Requirements on The Performance of ...

Ahmed Yousif Abd El-Razek

July 1988. The minimum capital to weighted assets and 8 per cent were implemented by the end of 1992 .

A new capital adequacy framework was issued in 2004 to replace the 1988 Agreement. This new framework, generally known as Basel II, was more adapted to the financial innovation that emerged in previous years and was aimed at improving the way in which regulatory capital requirements reflected fundamental risks (Jablecki, 2008). However, Basel II had a certain number of weaknesses that reinforced the depth and severity of the financial and economic crisis of the past decade.

Indeed, banks had excessive power, low capital and inadequate capital, and insufficient liquidity. Moreover, the second capital adequacy framework focused too much on individual financial institutions, while ignoring the interconnectedness of the important banks of the system. The systemic risk is compounded by the doubling of failure from one institution to another. The Basel Committee had to respond to all these weaknesses in order to improve the banking sector's ability to absorb shocks from economic and financial stress (Bank for International Settlements, 2018).

Between July 2009 and September 2010, the Commission and the Heads of Oversight issued the first version of Basel III regulatory reform. The main objectives followed by this third framework were to increase the level of equity in order to deal with potential losses and to reduce the risks to which institutions

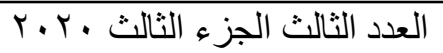

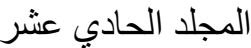


The Impact of the Basel Capital Requirements on The Performance of ...

Ahmed Yousif Abd El-Razek

operate. These goals can be reached through improvements in four different areas: capital enhancement, global liquidity standard, risk coverage and leverage (Gual, 2011). Most reforms are implemented in phases between 2013 and 2019.

The new Basel III system aims to make the global financial system safer and avoid a repeat financial and economic crisis.

\section{2) Research Problem}

With the implementation of the Basel framework, an important debate has emerged about the effect of the new capital requirements on the costs for banks and their performance measures. On the one hand, bankers and a certain number of scientists believe that a higher proportion of equity will be too expensive, lower the return on equity and reduce the ability of the financial institutions to provide loans to the economy. On the other hand, some theories suggest that the increased capital requirements may have a positive or neutral impact on bank's performance. In this case, banks should not worry about an increase of the capital ratios. Various empirical studies have been conducted in order to verify the accuracy of the different arguments that are proposed. This study seeks to find out the The Impact of the Basel Capital Requirements on The Performance of Egyptian Banks to answer the main research question :

1) Is there a difference in financial performance after applying Basel II committee?

$$
\text { العدد الثالث الجزء الثالث · r · r }
$$

المجلد الحادي عشر 
The Impact of the Basel Capital Requirements on The Performance of ...

Ahmed Yousif Abd El-Razek

2) What is effect of Capital Adequacy in the period (2009-2018) on Financial Indicators?

\section{3) Research Objectives}

The main objective of this study is research to Impact of the Basel Capital Requirements on The Performance of Egyptian Banks The specific objectives are:

- Investigate the The Impact of the Basel Capital Requirements on The Performance of Egyptian Banks, by research to effect of Capital Adequacy in the period (20092018) on Financial Indicators.

- Research of difference in financial performance after the application of Basel II in terms of capital adequacy for the period (2004-2007) to the period (2009-2012)

\section{4) Study Hypotheses}

This paper will study the link between the Basel II capital requirements and the performance measures by using recent data of banks in Egypt. The goal of this empirical research is to test the following hypotheses:

- H1: Financial Indicators Improved After The Application Of Basel II With Capital Adequacy Ratio For the period (2004-2007) to period (2009-2012)

○ H1.1: ROA Improved After The Application Of Basel II With Capital Adequacy Ratio For the period (2004-2007) to period (2009-2012)

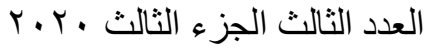

المجلد الحادي عشر 
The Impact of the Basel Capital Requirements on The Performance of ...

Ahmed Yousif Abd El-Razek

oH1.2: ROE Improved After The Application Of Basel II With Capital Adequacy Ratio For the period (2004-2007) to period (2009-2012)

oH1.3: Net Interest Margin Improved After The Application Of Basel II With Capital Adequacy Ratio For The Period (20042007) to period (2009-2012)

$\circ$ H1.4: Non-Performing Loans Improved After The Application Of Basel II With Capital Adequacy Ratio For The Period (20042007) to period (2009-2012)

- H2: There is a positive effect of Capital Adequacy in the period (2009-2018) on Financial Indicators

$\circ \mathrm{H}$ 2.1: There is a positive effect of Capital Adequacy in the period (2009-2018) on ROA Ratio

$\circ$ H2.2: There is a positive effect of Capital Adequacy in the period (2009-2018) on ROE Ratio

$\circ$ H2.3: There is a positive effect of Capital Adequacy in the period (2009-2018) on Net Interest Margin.

$\circ$ H2.4: There is a negative effect of Capital Adequacy in the period (2009-2018) on Non-Performing Loans.

\section{5) Capital Adequacy ratio, Return on Asset (ROA) and Return on Equity (ROE)}

This study examined the relationship between Capital adequacy, Cost Income ratio and performance of banks in Ghana. The study used data for a sample of banks listed on the Ghana Stock

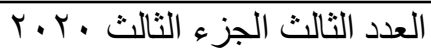

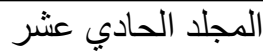


The Impact of the Basel Capital Requirements on The Performance of ...

Ahmed Yousif Abd El-Razek

Exchange for the period from 2013 to 2018.The study measured the bank profitability by return on assets (ROA), and return on equity (ROE) and Net Interest Income. Control variables were used in this study include Debt to Equity Ratio (DE), Assets Growth and Bank Size. The study concluded that capital adequacy is negatively related to performance, as measured by return on assets (ROA) and return on equity (ROE) However, it is statistically insignificant against return on assets but significant in the case of return on equity.( Antwi, 2019)

This study examined the Effect of Capital Adequacy Ratio (CAR) on Profitability of Deposit Money Banks with international operating license in Nigeria for the year 2017.

The study applied OLS method via SPSS 20.0 to run the data used. The study used Return on Assets (ROA) to measure the profitability of deposit money bank. The results showed that there exists a strong positive relationship between Capital Adequacy and Profitability of DMB'S in Nigeria. Thus; CAR proves a strong factor in profit planning and capital structure decisions. ( Olatayo et.al, 2019)

This study aims to examine the impact of capital adequacy ratio on profitability under Basel II in Bangladesh assessed by 29 listed banks for the time period of eight years from 2007 to 2014. The study used Return on Asset (ROA) and Return on Equity (ROE) as measure of banks profitability (dependent

$$
\text { r. العدد الثالث الجزء الثالث }
$$$$
\text { المجلد الحادي عشر }
$$ 
The Impact of the Basel Capital Requirements on The Performance of ...

Ahmed Yousif Abd El-Razek

variables).The study concluded that capital adequacy ratio is positively related to bank profitability. (Datta et.al, 2018)

This study aims to find out the effect of capital Adequacy on profitability in two banks SAMBA and SABB of Saudi Arabia for the period from 2010 to 2015 for both banks. The study considered Return on Assets (ROA) and Return on Equity (ROE) to measure the bank profitability. By applying Pearson's Correlation Analysis, the study found that there is a positive correlation relationship between the variables (Almazari et.al, 2017)

This study aims to identify the most important the requirements of Basel 3 and the differences between them and Basel II and Basel 1 and study the impact of the application of some of these items (adequacy of capital - financial leverage liquidity) on the performance of commercial banks in Jordan. The study included Jordanian commercial banks listed on the ASE between 2008 and 2014 after the global crisis.The study concluded that There is no relationship between the capital adequacy ratio and both ROA and ROE. There is no relationship between The Non-performing loans and ROE, on the other hand There is negative relationship between The Non-performing loans and ROA. There is negative relationship between The Liquidity Ratio and both ROA and ROE. There is negative 
The Impact of the Basel Capital Requirements on The Performance of ...

Ahmed Yousif Abd El-Razek

relationship between The Debt ratio (Leverage) and both ROA and ROE.( Elshalby.A, 2017)

The study aims to clarify the impact of financial risks of commercial banks in Oman for the period 2008-2015. The statistical program EVIEWS was used for statistical analysis with a descriptive analytical statistical method and PANAL DATA was used to test the study hypotheses. For the study, the following variables (credit risk, interest rate risk, liquidity risk and capital adequacy risk) were tested as independent variables with those dependent variables as an indicator of financial performance (ROE - ROA - EPS - share turnover) and data were extracted from the annual financial statements for banks included in the study, which includes all commercial banks in Oman and a number (13) banks. The study concluded that there is no significant relationship between liquidity risk, interest rate risk and financial performance of banks. There is an effective relationship between credit risk, capital adequacy risk and banks financial performance.( Wahdan.TH, 2017)

This study aims to clarify the impact of capital adequacy on the profitability of private commercial banks in Syria, which were listed on the Damascus Securities Exchange in 2009, including 6 banks for the period from 2009 to 2014. Capital adequacy was considered as the independent variable including (the Basel II capital adequacy ratio (CAR) - equity to deposits $(\mathrm{CAD})$ - equity to total assets (CAA) - equity to risk weighted

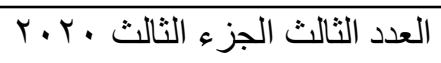

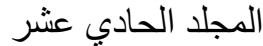


The Impact of the Basel Capital Requirements on The Performance of ...

Ahmed Yousif Abd El-Razek

assets (CARA)) and Profitability indicators are the dependent variable including (ROE - ROA - ROS).The financial statements of these banks were relied on to collect the data and then analyzed using a number of statistical methods, it's the simple regression of the study variables for each bank as well as the use of PANAL DATA by applying the regression model of banks as a whole and then the multiple regression of banks combined using SPSS 19.The study concluded that there is no statistically significant relationship between the Basel II capital adequacy ratio (CAR), equity to deposits (CAD), equity to total assets (CAA), equity to risk weighted assets (CARA) and (ROE - ROA - ROS).(ELSuwoq.R, 2017)

\section{6) Capital Adequacy ratio and Net Interest Margin}

The study aims to determine the impact of Capital Adequacy Ratio in Vietnam for 26 commercial banks for the period from 2010 to 2013. The variables of the study are, capital Adequacy ratio (CAR), Net interest margin (NIM), Bank size, GDP Growth, Interest rate and Exchange rate, Leverage and Deposits.

By applying Panel Tobit model, the study concluded that the Net interest margin (NIM), Bank size, GDP Growth, Interest rate and Exchange rate have the inverse relationship with CAR while the Leverage and Deposits positively correlated to CAR. ( Linh et.al, 2019)

$$
\text { العدد الثالث الجزء الثالث . r r r }
$$

المجلد الحادي عشر 
The Impact of the Basel Capital Requirements on The Performance of ...

Ahmed Yousif Abd El-Razek

This study aims to find the Determinants of Capital Adequacy Ratio (CAR) in Vietnam banks in the period 20112015. the study used asset of the bank (size), loans in total assets (LOA), leverage, net interest margin (NIM), loans lost reserve (LLR), Cash and Precious Metals in total assets (LIQ) as independent variables while capital adequacy ratio (CAR) as dependent variable.The study concluded that Bank size and Leverage have no impact on the capital adequacy ratio. While Net interest margin and Liquidity have a significant positive impact on the capital adequacy ratio. finally, Loans ratio is inversely related to the capital adequacy ratio in the Vietnamese banking system.( Thoa, 2017)

This study aims to test and determine the Bank's health level consisting of capital adequacy ratio (CAR), net interest margin (NIM), and non-performing loans (NPL) on bank profitability based on data from the Indonesian Stock for the population of this study is all state and private banks listed in the Indonesian Stock Exchange (ISE) amounting to 40. Observations are conducted from 2012 to 2016. Bank profitability was measured by Return on Assets (ROA) as a dependent variable.The study concluded that Capital adequacy ratio (CAR) does not have a significant effect on banking profitability. Net interest margin (NIM) has the effect to improve the growth of bank profitability while Non performing loans

$$
\text { r. العدد الثالث الجزء الثالث }
$$

المجلد الحادي عشر 
The Impact of the Basel Capital Requirements on The Performance of ...

Ahmed Yousif Abd El-Razek

(NPL) have a negative effect on bank profitability. ( Silaban, 2017)

This study investigated the effect of Basel capital regulation on bank profitability in Nigeria. A sample of 6 banks out of 24 banks are examined for 8-year period 2006 to 2013.

The study considered Return on Assets (ROA) and Net Interest Margin (NIM) as dependent variables to measure bank profitability. The independent variables included Capital adequacy ratio (CAR). The study concluded Basel capital regime had no significant effect on bank profitability.

after employing NIM and ROA profitability metrics, the study found that the determinants of bank profitability, and its significance, depends on the profitability metric employed. Finally, bank capital adequacy ratio is observed to be a significant determinant of bank profitability.( Ozili, 2015)

This study aims to examine to influence of capital adequacy ratio (CAR) in the Egyptian commercial banks covers 36 banks during the period from 2004 to 2013. The study considered capital adequacy ratio (CAR) as dependent variable and the independent variables are earning assets ratio, profitability, and liquidity, Loan loss provision as measure of credit risk, net interest margin growth, size, loans assets ratio and deposits assets ratio.

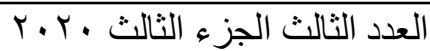

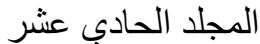


The Impact of the Basel Capital Requirements on The Performance of ...

Ahmed Yousif Abd El-Razek

The study concluded that before year 2008, Assets quality and return on equity (ROE) are significantly correlated negatively with the capital adequacy ratio. Management quality and net interest income have no impact on capital adequacy ratio while return on assets (ROA) is significantly correlated positively with the capital adequacy ratio In addition to, after year 2008 to 2013, Profitability showed no impact on the capital adequacy ratio. Liquidity, Management quality and Asset quality is significantly correlated positively to the capital adequacy ratio. Finally, Size of the bank is significantly correlated negatively to the capital adequacy ratio.( El-Ansary et.al, 2015)

\section{7) Capital Adequacy ratio and Non-Preforming Loans}

This study aims to analyze the effect of capital adequacy ratio (CAR), loan to deposit ratio (LDR) and inefficiency on nonperforming loans at 41 commercial banks in Indonesia for the period from 2016 - 2018. The study considered the Capital Adequacy Ratio (CAR), Loan to Deposit Ratio (LDR) and Operational Costs Operating Income as independent variables while non-performing loan as dependent variable .

The result showed that capital adequacy ratio (CAR), loan to deposit ratio (LDR), and operational costs operating income simultaneously affected NPL. Partially, CAR showed a negative result but does not significantly influence NPL.

$$
\text { r. العدد الثالث الجزء الثالث }
$$

المجلد الحادي عشر 
The Impact of the Basel Capital Requirements on The Performance of ...

Ahmed Yousif Abd El-Razek

While LDR and operational costs operating income proved to be a positive and significant effect on NPL.( Ruslim et.al, 2019)

This study aims to examine the determinants of nonperforming financing period from 2013 to 2018 in Indonesia Islamic Bank. The dependent variable used in this study is the non performing financing. Furthermore, the independent variables are Capital Adequacy Ratio (CAR), Financing to Deposit Ratio (FDR) and Bank Indonesia Sharia Certificates (SBIS). The results showed that the CAR and FDR have a significant negative effect on NPF. While, the SBIS rate has not affect on NPF.( Wulandari et.al, 2019)

The study aims to analyze the effect of capital adequacy and bank size on non-performing loans in public banks in Indonesia for the period from 2012 to 2016. The study considered Capital Adequacy Ratio (CAR), Bank Size and Loan to Deposit Ratio (LDR) as independent variables while NonPerforming Loan (NPL) as dependent variables.The study concluded that simultaneously capital adequacy ratio, bank size, and loan to deposit ratio have an effect on non-performing loans.

Partially, the result showed that capital adequacy ratio has a positive effect on non-performing loans, while bank size negatively affects nonperforming loans, and loan to deposit ratio negatively affects nonperforming loans (Yulianti et.al, 2018)

r. العدد الثالث الجزء الثالث

المجلد الحادي عشر 
The Impact of the Basel Capital Requirements on The Performance of ...

Ahmed Yousif Abd El-Razek

The study aims to examine and identify factors specific to commercial banks that contribute to the occurrence of nonperforming loans in Tanzania. The study collected data for 16 licensed and registered commercial bank for the period from 2007 to 2015. The study used Non-performing loans ratio dependent variables while independent variables are loan growth rate, Asset Growth, Deposit Growth and Capital Adequacy ratio.

By applying OLS regression technique, fixed effect and Random effect, the study concluded that cost-to-income is significantly positively correlated with Non-performing loans (NPLs), while asset growth and net interest margin are significantly negatively correlated with NPLs. The study found that other variables such as bank size, loan growth, deposit growth, capital adequacy ratio, and loan-to-assets ratio are negatively correlated with NPLs, but the relationship is not statistically significant. (Kingu et.al, 2018)

This study aims to analyze the influence of Capital Adequacy, Profitability, Loan Growth on Non-performing loans at the commercial banks in Tanzania for 10 years from 2005 to 2014

The study used Capital Adequacy, Return on Asset, Noninterest Expenses, Loans to Total Assets, Interest Margin as independent variables while Non-Performing loans ratio as dependent variable.The study concluded that capital Adequacy,

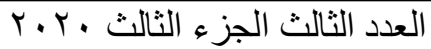

المجلد الحادي عشر 
The Impact of the Basel Capital Requirements on The Performance of ...

Ahmed Yousif Abd El-Razek

profitability posed insignificant influence on non-performing loans whereas loan to asset ratio and interest margin had a significant influence.( Malimi, 2017)

\section{8) Study Methodology}

In This Study, The Researcher Relied on The Descriptive and Analytical Statistical Method to Show the Effect of Basel Capital Requirements on The Financial Performance of Commercial Banks in Egypt .The Study Will Use the Statistical Program (Eviews) In the Process of Analysis and Hypothesis Testing. The Linear Regression Model Will Be Applied Using The Method Of The Ordinary Least Squares And The T-Test To Determine The Relationship Between The Variables Where The Dependent Variable Represents The Performance Of The Bank Which Is A Return On Equity, Return On Assets And Net Interest Margin, On The Other Hand Independent Variable Represents Capital Adequacy Ratio And Controlled Variable Are Bank Size And Time Period, The Study Was Divided Into Three Periods, The First Period Of The Year 2004 To 2007 , And The Second Period Of The Year 2009 To 2012 To Study Basel II , In Addition To The Third Period From 2009 To 2018 Implementing The Basel II \&III Study, The (T) Test Is Used To Compare Financial Indicators Between The First And Second Periods To Study The Effect Of Basel II, And A Used Regression Analysis In The Second And Third To Arrive At A Study Model Regarding The Effect Of The Application Of Basel II and Basel III. 
The Impact of the Basel Capital Requirements on The Performance of ...

Ahmed Yousif Abd El-Razek

\section{8) Study population}

The study includes commercial banks operating in Egypt with the exclude of Islamic banks, specialized banks and branches of foreign banks, sample includes 31 banks from a total of 39 banks. Study period from 2004 to 2018, The period from 2004 to 2012, we were divided into two periods. The first period of 2004-2007 and The exclusion of 2008 due to the global crisis, which represents the period of time prior to the application of Basel II to the Capital Adequacy Requirements and the second period 2009-2012, which represents the period of time after application of the Basel II Capital Adequacy Requirements. Then study the effect of the application of Basel II\&III to the Capital Adequacy Requirements on the performance of commercial banks in Egypt during the period from 2009 to 2018 in preparation for future studies in this field

9) Model

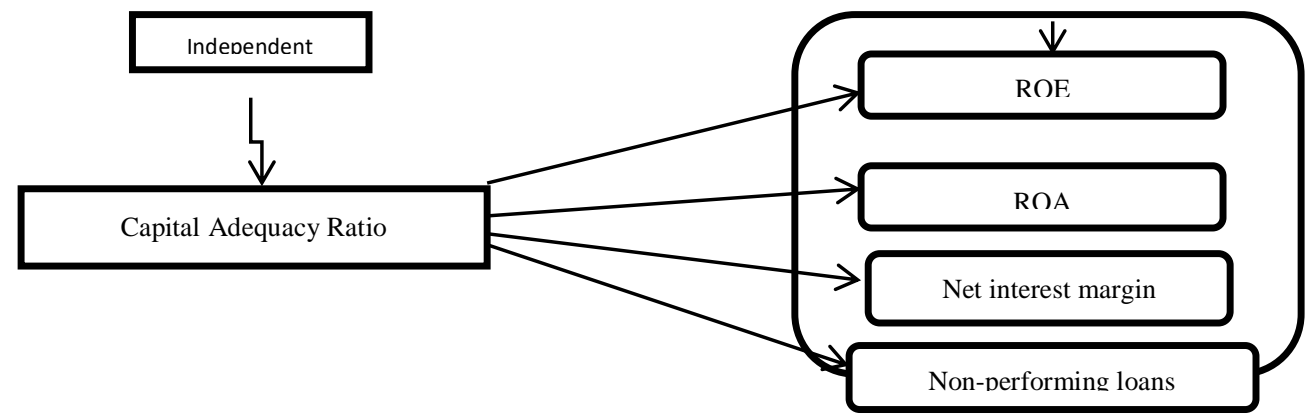

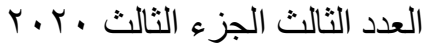

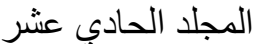


The Impact of the Basel Capital Requirements on The Performance of ...

Ahmed Yousif Abd El-Razek

Figure 1: Model of the Research Variables

\section{0) Statistical differences test of period comparisons (2004- 2007)to (2009-2012)}

Table (1) shows the (T) tests for the first variable (ROA) (ROE)(NIM)(NPL), to compare the period (2004-2007) with the period (2009-2012) with use Capital Adequacy Requirements (CAR), The probability must be less than $5 \%$ to ensure improvement in the financial index.

Table (1)

Execution (T) test of the period

comparisons (2004-2007) to (2009-2012)

\begin{tabular}{|c|l|c|c|}
\hline Variable & \multicolumn{1}{|c|}{ Method } & Value & Probability \\
\hline \multirow{2}{*}{ ROA } & t-test & 7.357005 & 0.00000 \\
\cline { 2 - 4 } & Anova F-test & 45.104616 & 0.00000 \\
\hline \multirow{2}{*}{ ROE } & t-test & 5.160988 & 0.00002 \\
\cline { 2 - 4 } & Anova F-test & 12.025917 & 0.00002 \\
\hline \multirow{2}{*}{ NIM } & t-test & 6.130838 & 0.00000 \\
\cline { 2 - 4 } & Anova F-test & 37.58718 & 0.00000 \\
\hline \multirow{2}{*}{ NPL } & t-test & -2.275965 & 0.02370 \\
\cline { 2 - 4 } & Anova F-test & 5.180015 & 0.02370 \\
\hline
\end{tabular}

Table (1) shows the statistical value to $\mathrm{T}$ test for effect Capital Adequacy Requirements (car) to the variable Return On Assets (ROA), in period (2004-2007) to period (2009-2012), the T test result shows the value t-statistics (7.357005) At the Probability (0.000) which is smaller than 0.05 statistically acceptable , and Fstatistics (45.104616) At the Probability (0.000) which is smaller 
The Impact of the Basel Capital Requirements on The Performance of ...

Ahmed Yousif Abd El-Razek

than 0.05 statistically acceptable, is believed that present findings provide a significant contribution confirming to positive Improved (ROA) After The Application use Of Basel II With Capital Adequacy Ratio OF period (2009-2012)

effect Capital Adequacy Requirements (CAR) to the variable Return on Equity (ROE), in period (2004-2007) to period (20092012), the $T$ test result shows the value t-statistics (5.160988) At the Probability $(0.000)$ which is smaller than 0.05 statistically acceptable , and F- statistics (12.025917) at the Probability (0.000) which is smaller than 0.05 statistically acceptable, is believed that present findings provide a significant contribution confirming to positive Improved (ROE) After The Application use of Basel II With Capital Adequacy Ratio of period (2009-2012)

and effect Capital Adequacy Requirements (CAR) to the variable Net Interest Margin (NIM), in period (2004-2007) to period (2009-2012), the test result shows the value t-statistics (6.130838) At the Probability (0.000) which is smaller than 0.05 statistically acceptable, and F- statistics (37.58718) At the Probability $(0.000)$ which is smaller than 0.05 statistically acceptable, is believed that present findings provide a significant contribution confirming to positive Improved Net Interest Margin (NIM) After The Application use Of Basel II With Capital Adequacy Ratio OF period (2009-2012)

and effect Capital Adequacy Requirements (CAR) to the variable Non-Performing Loans (NPL), in period (2004-2007) to

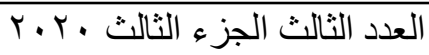

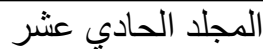


The Impact of the Basel Capital Requirements on The Performance of ...

Ahmed Yousif Abd El-Razek

period (2009-2012), the test result shows the value t-statistics (2.275965) At the Probability (0.0237) which is smaller than 0.05 statistically acceptable and F- statistics (5.180015) At the Probability (0.0237) which is smaller than 0.05 statistically acceptable, is believed that present findings provide a significant contribution confirming to Improved Non-Performing Loans (NPL). It had decreased After the Application use of Basel II With Capital Adequacy Ratio OF period (2009-2012)

\section{1) Regression and Granger's Causality test to period (2009-2018)}

Regression and Granger's Causality is applied between the research variables (CAR) (independent variable) and Return on Equity (ROE) \& Return on Assets (ROA) \& Net Interest Margin (NIM) \& Non-Performing Loans variables (NPL) (dependent variables), To measure the degree of impact (CAR) on Financial Indicators .

Table (2) shows the Regression test for Measure the effect (CAR) variable on Return on Assets (ROA), The probability must be less than $5 \%$ to ensure improvement in the financial index.

Table (2)

Regression test for the Research Variable

\begin{tabular}{|c|c|c|c|c|c|}
\hline Variable & $\mathrm{R}^{2}$ & Method & Value & Regression equation & Prob. \\
\hline \multirow{2}{*}{ ROA } & \multirow{2}{*}{$4.09 \%$} & t-test & 9.687067 & \multirow{2}{*}{$\begin{array}{c}=0.012927+\left(0.124706^{*}\right. \\
\text { CAR_X })+0.000544\end{array}$} & \multirow{2}{*}{0.0063} \\
\hline & & Anova F-test & 4.292016 & & \\
\hline \multirow{2}{*}{ ROE } & \multirow{2}{*}{$5.16 \%$} & t-test & 6.407038 & \multirow{2}{*}{$\begin{array}{c}=0.159327+(0.032934 * \\
\\
\text { CAR_X })+0.000660\end{array}$} & \multirow{2}{*}{0.0301} \\
\hline & & Anova F-test & 19.79755 & & \\
\hline
\end{tabular}

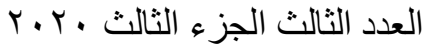

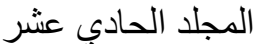


The Impact of the Basel Capital Requirements on The Performance of ...

Ahmed Yousif Abd El-Razek

\begin{tabular}{|c|l|l|r|c|c|}
\hline \multirow{2}{*}{ NIM } & \multirow{2}{*}{$8.95 \%$} & t-test & 5.228778 & $\begin{array}{c}=0.134287+(0.808964 * \\
\text { CAR_X)+0.000438 }\end{array}$ & 0.0000 \\
\cline { 3 - 4 } & & Anova F-test & 27.34012 & \\
\hline \multirow{2}{*}{ NPL } & \multirow{2}{*}{$5.69 \%$} & t-test & -3.74210 & $\begin{array}{l}=0.069623+(-0.16335 * \\
\text { CAR_X)+ }\end{array}$ & 0.004087 \\
\cline { 3 - 4 } & & Anova F-test & 5.180015 & 0.0322 \\
\hline
\end{tabular}

Table (2) test shows that there is integration between the variables, Show the following results:

- There is an effect to ( CAR) On ( ROA), the test result shows probability less than $5 \%$ and value $\mathrm{R}^{2}(4.09 \%)$ and value Adjusted $-\mathrm{R}^{2}(3.96 \%)$ At the Probability (0.006) , and Fstatistics (4.2920) which is smaller than 0.05 statistically acceptable, is believed that present findings provide a effect of Capital Adequacy on (ROA) .

- There is an effect to ( CAR) On ( ROE), the test result shows probability less than $5 \%$ and value $\mathrm{R}^{2}(4.15 \%)$ and value Adjusted $-\mathrm{R}^{2}(4.92 \%)$ At the Probability (0.000135), and Fstatistics (19.79755) which is smaller than 0.05 statistically acceptable, is believed that present findings provide a effect of Capital Adequacy on (ROE) .

- There is an effect to ( CAR) On ( NIM), the test result shows probability less than $5 \%$ and value $\mathrm{R}^{2}(8.95 \%)$ and value Adjusted $-\mathrm{R}^{2}(8.73 \%)$ At the Probability $(0.000000)$, and Fstatistics (27.34012) which is smaller than 0.05 statistically acceptable, is believed that present findings provide a effect of Capital Adequacy on (NIM) . 
The Impact of the Basel Capital Requirements on The Performance of ...

Ahmed Yousif Abd El-Razek

- There is an effect to ( CAR) On ( NPL), the test result shows probability less than $5 \%$ and value $\mathrm{R}^{2}(5.69 \%)$ and value Adjusted $-\mathrm{R}^{2}(5.46 \%)$ At the Probability (0.022201) , and Fstatistics (5.034945) which is smaller than 0.05 statistically acceptable, is believed that present findings provide a effect of Capital Adequacy on (NPL), But the relationship is negative between Capital Adequacy Requirements and NonPerforming Loans.

\section{2) conclusion:}

1. The results of the study found Financial Indicators (ROA\&ROE\&NIM\&NPL) Improved After The Application Of Basel II With Capital Adequacy, was accepted hypothesis " H1: Financial Indicators Improved After The Application Of Basel II With Capital Adequacy Ratio For the period (2004-2007) to period (2009-2012)"

2. The results of the study found " ROA Improved After The Application Of Basel II With Capital Adequacy Ratio For the period (2004-2007) to period (2009-2012)" at Probability (0.000) which is smaller than 0.05 statistically acceptable, and t-test (7.357005) At the Probability (0.000) which is smaller than 0.05 statistically acceptable, is believed that present findings provide a significant contribution confirming to positive Improved (ROA) After The Application use Of Basel II With Capital Adequacy Ratio OF period (2009-2012), According The Results Of Statistical 
The Impact of the Basel Capital Requirements on The Performance of ...

Ahmed Yousif Abd El-Razek

Tests Accept The Sub-Hypothesis That " ROA Improved After The Application Of Basel II With Capital Adequacy Ratio For the period (2004-2007) to period (2009-2012)"

3. The results of the study found " ROE Improved After The Application Of Basel II With Capital Adequacy Ratio For the period (2004-2007) to period (2009-2012)" at the Probability (0.000) which is smaller than 0.05 statistically acceptable, and T-test (5.160988) At the Probability (0.000) , is believed that present findings provide a significant contribution confirming to positive Improved (ROE) After The Application use Of Basel II With Capital Adequacy Ratio OF period (2009-2012), According The Results Of Statistical Tests Accept The Sub-Hypothesis That " ROE Improved After The Application Of Basel II With Capital Adequacy Ratio For the period (2004-2007) to period (2009-2012)"

4. The results of the study found " Non-Performing Loans Improved After The Application Of Basel II With Capital Adequacy Ratio For the period (2004-2007) to period (2009-2012)" at the Probability (0.000) which is smaller than 0.05 statistically acceptable, and T-test(-2.275965) At the Probability (0.000) , is believed that present findings provide a significant contribution confirming to positive Improved (NIM) After The Application use Of Basel II With Capital Adequacy Ratio OF period (2009-2012) ,According The

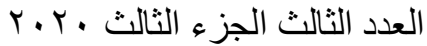

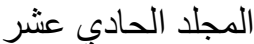


The Impact of the Basel Capital Requirements on The Performance of ...

Ahmed Yousif Abd El-Razek

Results Of Statistical Tests Accept The Sub-Hypothesis That " Non-Performing Loans Improved After The Application Of Basel II With Capital Adequacy Ratio For The Period (20042007) to period (2009-2012)"

5. The results of the study found " Non-Performing Loans Improved After The Application Of Basel II With Capital Adequacy Ratio For the period (2004-2007) to period (2009-2012)" at the Probability (0.0237) which is smaller than 0.05 statistically acceptable , and T-test(-2.275965) At the Probability (0.0237) , is believed that present findings provide a significant contribution confirming to Improved (NPL) It had decreased After The Application use Of Basel II With Capital Adequacy Ratio OF period (2009-2012), According The Results Of Statistical Tests Accept The Sub-Hypothesis That " Non-Performing Loans Improved After The Application Of Basel II With Capital Adequacy Ratio For The Period (2004-2007) to period (2009-2012)"

6. The results of the study found Financial Indicators (CAR) effict on Financial Indicators (ROA\&ROE\&NIM\&NPL), Since applying Basel II \& III With Capital Adequacy, can accepted hypothesis " H2: There is a positive effect of Capital Adequacy in the period (2009-2018) on Financial Indicators " this result from Statistical tests correspond to ,

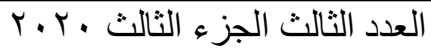

المجلد الحادي عشر 
The Impact of the Basel Capital Requirements on The Performance of ...

Ahmed Yousif Abd El-Razek

7. The results of the study found positive Relationship between the variables, which means There is an effect to ( CAR) On ( ROA) at probability less than 5\%, R2 (4.09\%), adjusted value-R2 (3.96\%) at probability (0.006), and F- (4.2920) statistics that are less than 0.05 statistically acceptable. These current results present the effect of capital adequacy on (ROA), according to the results of statistical tests accepting the hypothesis that "There is a positive effect of capital adequacy in the period (2009-2018) on the ratio of ROA"

8. The results of the study found positive Relationship between the variables, which means There is an effect to ( CAR) On ( ROE) at probability less than $5 \%$ and value $\mathrm{R}^{2}(4.15 \%)$ and value Adjusted $-\mathrm{R}^{2}(4.92 \%)$ At the Probability (0.0301), and F- statistics (19.79755) which is smaller than 0.05 statistically acceptable, is believed that present findings provide a effect of Capital Adequacy on (ROE) . According The Results Of Statistical Tests Accept The Sub-Hypothesis That " There is a positive effect of Capital Adequacy in the period (2009-2018) on ROE Ratio"

9. The results of the study found positive Relationship between the variables, which means There is an effect to ( CAR) On ( NIM) at probability less than $5 \%$ and value $\mathrm{R}^{2}(8.95 \%)$ and value Adjusted $-\mathrm{R}^{2}(8.73 \%)$ At the Probability (0.000000), and F- statistics (27.34012) which is smaller than 0.05 statistically acceptable, is believed that present findings 
The Impact of the Basel Capital Requirements on The Performance of ...

Ahmed Yousif Abd El-Razek

provide a effect of Capital Adequacy on (NIM) . According The Results Of Statistical Tests Accept The Sub-Hypothesis That " There is a positive effect of Capital Adequacy in the period (2009-2018) On Net Interest Margin"

10. The results of the study found Negative Relationship between the variables, which means There is an effect to ( CAR) On ( NPL) at probability less than $5 \%$ and value $\mathrm{R}^{2}(5.69 \%)$ and value Adjusted $-\mathrm{R}^{2}(5.46 \%)$ At the Probability (0.032201) , and F- statistics (5.034945) which is smaller than 0.05 statistically acceptable, is believed that present findings provide a effect of Capital Adequacy on (NPL) , But the relationship is negative between Capital Adequacy Requirements andNon-Performing Loans. According The Results Of Statistical Tests Accept The Sub-Hypothesis That " There is a negative effect of Capital Adequacy in the period (2009-2018) on NonPerforming Loans"

\section{3) Recommendations:}

1. The researcher recommends the boards of directors and risk management in the banks included in the research sample Increase the capital adequacy ratio by increasing the percentage of deduction of profits if they are achieved. It is better to face a lower rate of deduction in the event of losses. 
The Impact of the Basel Capital Requirements on The Performance of ...

Ahmed Yousif Abd El-Razek

2. The Central Bank continues to implement policies geared towards improving the performance of the banking sector and reflected on capital adequacy.

3. Egyptian commercial banks must work to maintain the capital adequacy ratio that guarantees them to maintain a strong financial position and allow them at the same time to increase their profitability and improve their performance.

4. The need for conference and workshops for specialists in the field of commercial banks, whether local or international, to discuss the results of the implementation of the decisions of the Basel 3 Committee and benefit from the experiences of different countries in how to apply them.

5. The need for commercial banks to disclose within their financial statements the foundations and rules by which the capital adequacy ratio is measured and determined for the purpose of increasing transparency and clarity in front of investors, depositors and regulatory bodies to enhance the bank's position and consolidate its role in developing the economy.

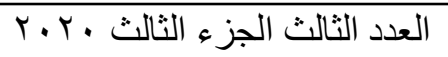

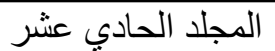


The Impact of the Basel Capital Requirements on The Performance of ...

Ahmed Yousif Abd El-Razek

\section{References :}

- Almazari et.al (2017). The Effect of Capital Adequacy on Profitability: A Comparative Study between Samba and Saab Banks of Saudi Arabia. International Journal of Economics, Commerce and Management. Vol. $\mathrm{V}$, Issue 11.

- Antwi, F. (2019). Capital Adequacy, Cost Income Ratio and Performance of Banks in Ghana. International Journal Academic Research in Business and Social Sciences, vol.9, No.10.

Settlements. (2013, January). Basel III: The Liquidity Coverage Ratio and liquidity risk monitoring tools. Retrieved from Bank for International Settlements: http://www.bis.org/publ/bcbs238.htm

- Datta et.al (2018). Impact of Capital Adequacy on Profitability Under Basel II Accord: Evidence from Commercial Banks of Bangladesh. European Journal of Business and Management. Vol.10, No.8.

- El-Ansary et.al (2015). Determinants of Capital Adequacy Ratio: An Empirical Study on Egyptian Banks. Corporate Ownership \& Control. Vol 13, No.1.

- Gual, J. (2011). Capital requirements under Basel III and their impact on the banking industry.Barcelona: La Caixa.

- Kingu et.al (2017). Bank Specific Determinants of Non-Performing Loans: Empirical Evidence from Commercial Banks in Tanzania. The International Journal of Business \& Management. Vol. 5, No.12.

- Linh (2019). Determinants of Capital Adequacy Ratio of Vietnamese Commercial Banks. International Journal of Business, Economics and Law, Vol. 18, No.5.

- Olatayo et.al (2019). Effect of Capital Adequacy Ratio (CAR) on Profitability of Deposit Money Banks (DMB's): A Study of DMB's with International Operating License in Nigeria. Research Journal of Finance and Accounting. Vol.10, No.10 
The Impact of the Basel Capital Requirements on The Performance of ...

Ahmed Yousif Abd El-Razek

- Ozili (2015). Determinants of Bank Profitability and Basel Capital Regulation: Empirical Evidence from Nigeria. Research Journal of Finance and Accounting. Vol.6, No.2.

- Ruslim et.al (2019). The Effect of Capital Aset and Liability Ratio on Non-Performing Loan. Jurnal Akuntansi. Vol. 23, No. 3

- Silaban (2017). The Effect of Capital Adequacy Ratio, Net Interest Margin and Non-Performing Loans on Bank Profitability: The Case of Indonesia. International Journal of Economics and Business Administration. Vol. V, No. 3.

- Thoa et.al (2017). The Determinants of Capital Adequacy Ratio: The Case of the Vietnamese Banking System in the Period 2011-2015. Journal of Science: Economics and Business, Vol. 33, No. 2.

- Wulandari (2019). Determinant of Non-performing Financing in Indonesia Islamic Bank. The 2nd International Conference on Islamic Economics, Business, and Philanthropy (ICIEBP) Theme: "Sustainability and Socio-Economic Growth". Vol.10, No. 3

- Yulianti et.al (2018). The Effect of Capital Adequacy and Bank Size on Non-Performing Loans in Indonesian Public Banks. Journal of Accounting Research, Organization and Economics Vol. 1, No.2.

- Malimi (2017). The Influence of Capital Adequacy, Profitability, and Loan Growth on Non- Performing Loans a Case of Tanzanian Banking Sector. International Journal of Economics, Business and Management Studies Vol. 4, No.1. 